\title{
A Manganese(II)-Dependent Extracellular Peroxidase from the White-Rot Fungus Trametes versicolor*
}

\author{
Tomas Johansson and Per Olof Nyman \\ Division of Biochemistry, Chemical Center, University of Lund, P.O. Box 124, S-221 00 Lund, Sweden
}

\begin{abstract}
Johansson, T. and Nyman, P. O., 1987. A Manganese(II)-Dependent Extracellular Peroxidase from the White-Rot Fungus Trametes versicolor. - Acta Chem. Scand., Ser. B 41: 762-765.
\end{abstract}

Ever since it became known that lignin and lignocellulose can be degraded by strongly oxidixing enzymes found in common wood-degrading organisms, primarily the white-rot basidiomycetes, efforts have been made to elucidate the properties and the roles of these enzymes. The most studied fungus, Phanerochaete chrysosporium, has been shown to produce a veratryl alcohol-oxidizing peroxidase called ligninase. ${ }^{1,2}$ Furthermore, a Mn(II)-dependent peroxidase has been identified. ${ }^{3,4}$ It has an oxidizing activity towards phenolic structures and is also supposed to be involved in the degradation of lignin. The Mn(II)dependent enzyme oxidizes $M n$ (II) to $M n(I I I)$, which in turn is able to oxidize various substrates. It is a true peroxidase which can utilize hydrogen peroxide in oxidizing low-molecular-weight phenols, thereby forming phenoxy radicals.

The ligninase and the Mn(II)-dependent peroxidase from $P$. chrysosporium have been purified and are now under study in several laboratories. Both enzymes occur in multiple forms as glycosylated heme proteins. It is unclear whether this heterogeneity is due to varying degrees of glycosylation or other post-translational modifications, or is caused by multiplicities of structural genes. $^{5}$

We have started investigations on another lignin-degrading fungus, namely the white-rot basidiomycete Trametes (Coriolus) versicolor. Our

\footnotetext{
*Communication at the Meeting of the Swedish Bio-
} chemical Society in Uppsala, August 21-22, 1987. aim is to find out whether the principles and pathways for enzymatic lignin degradation now emerging from studies on $P$. chrysosporium are also valid for other lignin-degrading systems. $T$. versicolor has long been known to produce laccases and to be effective in degrading lignins and lignocelluloses. ${ }^{6}$ It has recently been shown to produce ligninase. ${ }^{7,8}$ Here, we present evidence for the existence of an inducible $\mathrm{Mn}$ (II)-dependent peroxidase excreted from $T$. versicolor and some information concerning the properties of this enzyme.

\section{Experimental}

The organism Trametes versicolor (L.ex Fr.) Pilát, strain PRL 572, was grown in a carbon-limited medium according to Dodson et al., ${ }^{7}$ slightly modified for increased peroxidase production by using: $10 \times\left[\mathrm{FeSO}_{4}\right], 50 \times\left[\mathrm{CaSO}_{4}, \mathrm{MnSO}_{4}\right.$, $\mathrm{ZnSO}_{4}, \mathrm{CuSO}_{4}$, thiamin-HCl] and $10 \mathrm{mM}$ phosphate, giving a $\mathrm{pH}$ around 5. Stationary cultures $(300 \mathrm{ml}$ of culture fluid in $1000 \mathrm{ml}$ Erlenmeyerflasks) were induced from the start by inclusion of $10 \mathrm{mM}$ veratryl alcohol (final concn.), a concentration which had been found to increase peroxidase production. On the 11th day the medium was collected, filtered and dialysed against a 20 mM histidine buffer (pH 5.5) containing $10 \mathrm{mM}$ $\mathrm{NaCl}$. The dialysate $(500 \mathrm{ml})$ was subjected to chromatography on a $50 \mathrm{ml}$ Q-Sepharose column (Pharmacia) pre-equilibrated with $20 \mathrm{mM}$ histidine buffer (pH 5.5) containing $10 \mathrm{mM} \mathrm{NaCl}$. 


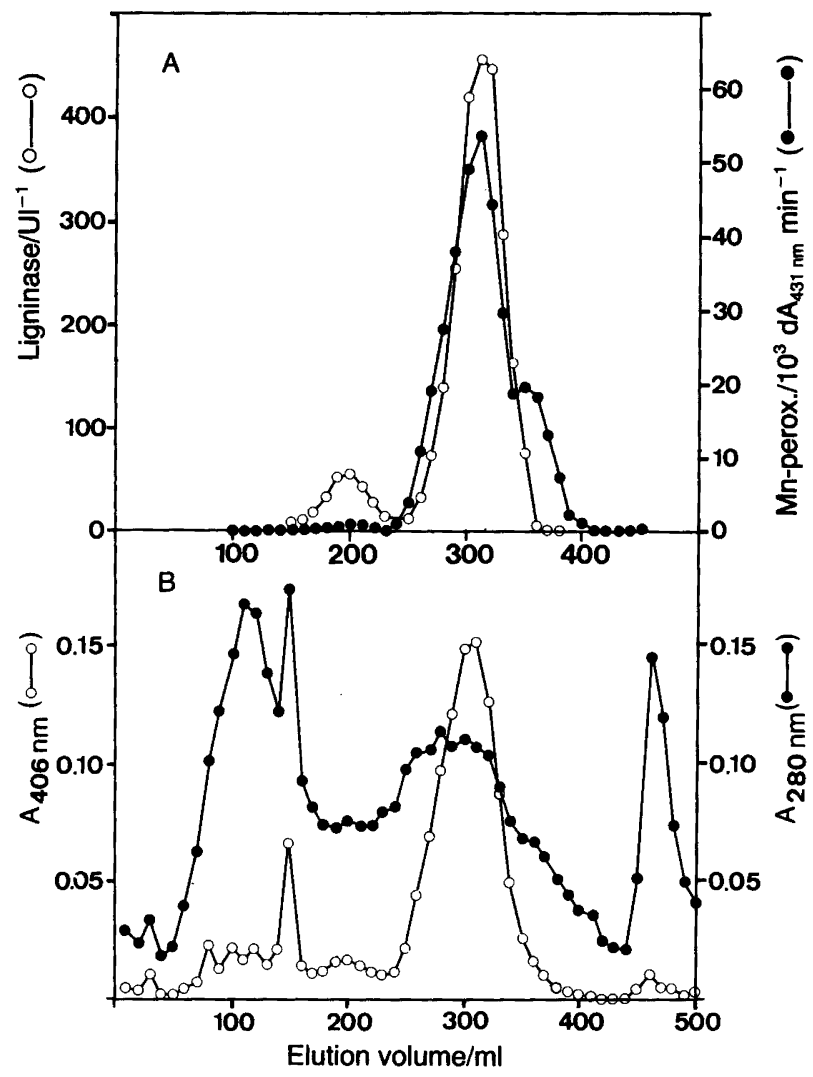

Fig. 1. Anion-exchange chromatography of medium from a culture of $T$. versicolor. A: Distribution of enzyme activities. The ligninase was found to oxidize phenol red with or without veratryl alcohol or $\mathrm{Mn}$ (II) added. The Mn(II)-peroxidase curve is therefore an accumulated profile contributed to by $\mathrm{Mn}(\mathrm{II})$-dependent peroxidase as well as ligninase. A unique contribution by $\mathrm{Mn}$ (II)-peroxidase at an elution volume of $360 \mathrm{ml}$ (Pool B) was selected for further purification, resulting in the isolation of two isozymes (see Fig. 3). B: Distributions of protein $\left(A_{280 \mathrm{~nm}}\right)$ and heme $\left(A_{406 \mathrm{~nm}}\right)$.
The column was eluted with the same buffer using a linear gradient of from 10 to $250 \mathrm{mM} \mathrm{NaCl}$ and employing a total volume of $300 \mathrm{ml}$. The elution rate was $4.5 \mathrm{ml} \mathrm{min}^{-1}$ and $10 \mathrm{ml}$ fractions were collected. Fractions corresponding to the peak of $\mathrm{Mn}$ (II)-dependent peroxidase activity (see Fig. 1) were pooled (Pool B), dialysed against the same buffer and separated further on a Mono Q HR 5/5 column connected to a FPLC apparatus (Pharmacia). In this way, two enzyme fractions were isolated (fractions I and II). After dialysis, they were concentrated using a Speed Vac concentrator (Savant) and analyzed by sodium dodecyl sulfate-polyacrylamide gel electrophoresis (SDS-PAGE) (Fig. 3) using a gradient gel $(12.6-20 \%)$ (Pharmacia) which was subsequently stained with Coomassie Brilliant Blue.

Ligninase activity was assayed spectrophotometrically by monitoring the change in absorbance at $310 \mathrm{~nm}$ corresponding to the oxidation of veratryl alcohol, as described by Kirk et al. ${ }^{9}$ but using 0.1 M Na-tartrate buffer, pH 2.9. Mn(II)- dependent peroxidase activity was measured as phenol red oxidation in the presence and absence of $\mathrm{MnSO}_{4} \cdot{ }^{4}$ For testing $\mathrm{Mn}(\mathrm{II})$-dependence, a constant amount of enzyme $(100 \mu \mathrm{l})$ and increasing amounts of $\mathrm{MnSO}_{4}$ were added up to a final reaction volume of $1 \mathrm{ml}$. Final concentrations in the reaction mixture were $0.0025 \%$ phenol red, $6.25 \mathrm{mM}$ lactate, $0.025 \%$ bovine serum albumin and $5 \mathrm{mM}$ 2,2-dimethylsuccinate buffer, $\mathrm{pH} 4.5$. The reaction was started by adding $9 \mu \mathrm{l}$ of $2 \mathrm{mM}$ $\mathrm{H}_{2} \mathrm{O}_{2}$ and run at room temperature. For testing $\mathrm{H}_{2} \mathrm{O}_{2}$-dependence the reaction was carried out in the presence of $0.30 \mathrm{mM} \mathrm{MnSO}_{4}$. We found that the reaction could be conveniently followed spectrophotometrically at $431 \mathrm{~nm}$, monitoring the decrease in substrate concentration.

\section{Results and discussion}

Evidence has been obtained for the production of a Mn(II)-dependent peroxidase by the white-rot basidiomycete $T$. versicolor, this enzyme possibly 


\section{SHORT COMMUNICATION}

playing a role in lignin degradation. Stationary cultures of the organism in a carbon-limited medium, induced by the addition of veratryl alcohol, were found to excrete the enzyme almost in parallel with the veratryl alcohol-oxidizing peroxidase (ligninase), but in smaller amounts. This pattern of induced peroxidase production resembles that described for another white-rot basidiomycete, $P$. chrysosporium. ${ }^{3}$

The enzyme shows properties of a peroxidase, oxidizing phenol red in the presence of $\mathrm{H}_{2} \mathrm{O}_{2}$ and $\mathrm{Mn}(\mathrm{II})$. The dependence of the reaction rate upon the concentrations of these reactants is shown in Fig. 2. The concentrations for optimal rate were found to be $0.30 \mathrm{mM}$ for $\mathrm{MnSO}_{4}$ and $0.020 \mathrm{mM}$ for $\mathrm{H}_{2} \mathrm{O}_{2}$. These concentrations differ from those given for the $\mathrm{Mn}(\mathrm{II})$-dependent peroxidase from $P$. chrysosporium, where corresponding values of $0.100 \mathrm{mM}$ and $0.100 \mathrm{mM}$ have been reported. ${ }^{4}$

The Mn(II)-dependent peroxidase was isolated from the growth medium of $T$. versicolor by repeated chromatographic steps. The first of these steps is illustrated in Fig. 1 as an elution profile from a Q-Sepharose column. The two peaks of ligninase activity (at 200 and $300 \mathrm{ml}$ of effluent volume, respectively) were investigated by SDSPAGE (Fig. 3). The material in the first peak shows a molecular mass significantly lower than for the two isozyme bands in the second peak. Besides the two peaks of lingninase activity, there is a shoulder of activity which could be separated into two isozymes of $\mathrm{Mn}$ (II)-dependent peroxidase. These isozymes seem to differ in

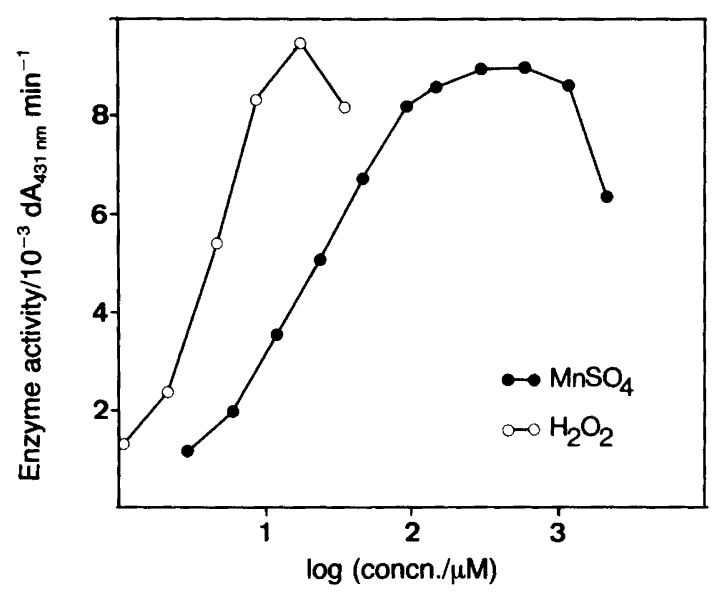

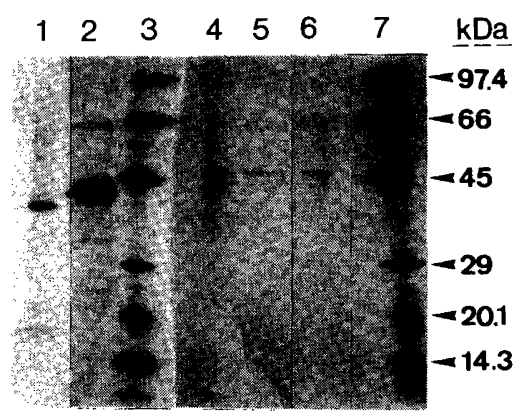

Fig. 3. Different Mn(II)-dependent peroxidase-containing fractions analyzed by SDS-PAGE. Lanes 3 and 7: Molecular mass standard. Lane 1: Top fraction from the first ligninase peak in Fig. 1 (around $200 \mathrm{ml}$ effluent volume). Lane 2: Top fraction from the second ligninase peak in Fig. 1 (around $300 \mathrm{ml}$ effluent volume), showing two isozyme bands (cf. Ref. 8). Lane 4: Pool $B$ [pooled fractions of $\mathrm{Mn}(\mathrm{II})$-dependent peroxidase peak at $360 \mathrm{ml}$ effluent volume in Fig. 1]. By rechromatography of pool B two enzyme fractions were obtained (I and II). Lane 5: Rechromatographed Pool B, fraction I, Lane 6: Rechromatographed Pool B, fraction II.

charge but not in molecular mass (Fig. 3). With the procedure used, both isozymes appear to be obtained in, or close to, a state of homogeneity sufficient for characterization of molecular properties.

Besides the Mn(II)-dependent peroxidase representing the shoulder of activity at $360 \mathrm{ml}$ of effluent volume (Fig. 1), a smaller contribution of $\mathrm{Mn}(\mathrm{II})$-dependent peroxidase, not further in-

Fig. 2. Manganese and $\mathrm{H}_{2} \mathrm{O}_{2}$-dependences of the oxidation of phenol red catalyzed by a peroxidase preparation from $T$. versicolor. The experiment was carried out with a partially purified preparation of Mn(II)-dependent peroxidase (Pool B from the chromatography in Fig. 1). 
vestigated, appears to occur at around $270 \mathrm{ml}$ of effluent volume.

The molecular mass of the two isozymes of $\mathrm{Mn}$ (II)-dependent peroxidase isolated from $T$. versicolor was estimated from electrophoretic mobility (Fig. 3) to be around $49000 \mathrm{Da}$, comparable to the value of $45000-47000 \mathrm{Da}$ reported for the corresponding enzyme from $P$. chrysosporium. ${ }^{3}$

As far as we know, this is the first description of a procedure for production and purification of a Mn(II)-dependent peroxidase from $T$. versicolor. The results obtained will be utilized in further studies of the enzyme and its role in the ligninolytic pathways of $T$. versicolor.

Acknowledgements. We are grateful to Dr. A. M. Rosengren for providing FPLC facilities and to Dr. R. Waldner, Zürich, for providing unpublished information. This work was supported by a grant from Nils och Dorthi Troedssons forskningsfond.

\section{References}

1. Glenn, J. K., Morgan, M. A., Mayfield, M. B., Kuwahara, M. and Gold, M.H. Biochem. Biophys. Res. Commun. 114 (1983) 1077.

2. Tien, M. and Kirk, T. K. Science 221 (1983) 661.

3. Paszcynski, A., Huynh, V.B. and Crawford, R. Arch. Biochem. Biophys. 244 (1986) 750.

4. Kuwahara, M., Glenn, J. K., Morgan, M. A. and Gold, M. H. FEBS Lett. 169 (1984) 247.

5. Leisola, M.S. A., Kozulic, B., Meussdoerffer, F. and Fiechter, A. J. Biol. Chem. 262 (1987) 419.

6. Crawford, R. L. Lignin Biodegradation and Transformation, Wiley, New York 1981.

7. Dodson, P. J., Evans, C. S., Harvey, P. J. and Palmer, J. M. FEMS Microbiol. Lett. 42 (1987) 17.

8. Jönsson, L., Johansson, T., Sjöström, K. and Nyman, P. O. Acta Chem. Scand., Ser. B 41 (1987) 766.

9. Kirk, T. K., Croan, S., Tien, M., Murtagh, K. E. and Farell, R. L. Enzyme Microb. Technol. 8 (1986) 27.

Received September 15, 1987. 